\title{
EU DATA PROTECTION AND THE PRINCIPLE OF PROPORTIONALITY
}

\author{
ESTER HERLIN-KARNELL*
}

This paper explores the principle of proportionality in the context of EU data protection. The paper starts by setting out the basics of EU data protection at the EU level and explains why it is so interesting in the context of proportionality. The paper will briefly set out some of the main debate on proportionality before looking at some recent $E U$ cases on data protection where the principle of proportionality has played a key role. The final part of the paper uses the Swedish derogations from the GDPR as a test case of a lack of proportionality.

\section{INTRODUCTION}

Why is data protection interesting from the perspective of proportionality? Or perhaps I should ask why proportionality is interesting from the perspective of data protection? The principle of proportionality has played a pivotal role in recent EU data protection cases.

This is not strange considering that in EU law, data protection is formulated as a right. Consequently, the right to data protection is codified in Article 16 TFEU and in Article 8 EU Charter. In addition, Article 7 EU Charter stipulates the right to privacy, communication and family life, and Article 8 ECHR also sets a general right to privacy, communication, home and family life.

It seems that the question of data protection is extremely important in the context of exactly proportionality, perhaps it is the most important principle for our understanding of the reach of data protection in the EU context. The notion of proportionality is of course a golden rule in EU law. Specifically, the principle of proportionality in EU law is taken to mean balancing the means and ends, in which the notion of appropriateness constitutes the golden thread for deciding on the desirability and need for EU action. Thus, proportionality is a classic in EU law and is one of the most crucial general principles, one which is used both as a sword and as a shield, usually in the context of to what degree the Member States could derogate from their EU law obligations. But it also constitutes one of the leading principles for deciding on whether EU legislative competence is warranted. ${ }^{1}$

The notion of proportionality is not an entirely straightforward principle, however. For example, Article $52 \mathrm{EU}$ Charter makes it clear that any permissible derogations by Member States from EU law obligations as set out in the Charter, are contingent on proportionality. In other words, proportionality is a doubled edged sword: the same principle of proportionality is protecting individual rights in a positive sense can also be used to limits

\footnotetext{
* Professor of EU Law, University of Gothenburg. The paper was presented at the conference on 'The consequences of Schrems II from practical and theoretical perspectives', 16 September 2021, Faculty of Law, University of Lund.

${ }^{1}$ In the context of data protection and proportionality see the chapters in Ulf Bernitz and others (eds), General Principles of EU Law and the EU Digital Order (Wolters Kluwer 2020). On proportionality in general and EU law, see, eg, Takis Tridimas, General Principles of EU Law (OUP 2012), chs 3-5.
} 
those rights. In other words, the Member States could invoke proportionality to derogate from the rights guaranteed in the Charter (Article 52). Proportionality appears to play a key role with regard to the Charter of Fundamental Rights more generally, both in its scope and in its application.

Many scholars have, of course, been interested in proportionality for a long time and there are very good reasons for such an extensive interest in the contours of proportionality. After all, the principle of proportionality has been viewed as intrinsic to the rule of law, and even as the ultimate rule of law. ${ }^{2}$ Moreover, for example, Mattias Kumm has observed that '[o]ne important function of proportionality analysis is to function as a filter device that helps to determine whether illegitimate reasons might have tilted the democratic process against the case of the rights-claimant'. ${ }^{3}$

Recently there has also been an increased interest in the similarities between the doctrine of the principle of proportionality and that of a right to justification advocated by Rainer Forst. ${ }^{4}$ The point of justification is that individuals have a right to reasoned decisions, and the function of courts is to assess whether the public authority taking the decision in question can be justified by public policy. Thus, the question of good reason is perhaps most clearly identified in the principle of proportionality, which functions as a justification tool. ${ }^{5}$ In addition, Mattias Kumm has referred to proportionality reasoning as a form of 'Socratic contestation', which refers to the practice of critically engaging authorities in order to assess whether the claims that they make are based upon good reason. ${ }^{6}$ Why is this so? In order to give the notion of justification concrete meaning in a legal context, it is often suggested we need to understand the principle of proportionality. ${ }^{7}$ This is because the principle of proportionality is an expression of the right to justification and could be connected to the idea of justice (at least in the legal sense) and the bigger issue of good governance.

This paper will set out to examine the importance of the principle of proportionality and the role it plays in the area of EU data protection cases. The paper will briefly explain what the principle of proportionality entails and will turn to some recent EU cases on data protection where the principle of proportionality has played a key role. The final part of the paper uses the Swedish derogations from the GDPR as a test case of a lack of proportionality.

\footnotetext{
2 David M Beatty, The Ultimate Rule of Law (OUP 2004) 56; Aharon Barak, Proportionality: Constitutional Rights and their Limitations (CUP 2012).

${ }^{3}$ Mattias Kumm, 'Alexy's Theory of Constitutional Rights and the Problem of Judicial Review' in Matthias Klatt (ed), Institutionalized Reason: The Jurisprudence of Robert Alexy (OUP 2012).

${ }^{4}$ Rainer Forst, The Right to Justification: Elements of a Constructivist Theory of Justice (Columbia University Press 2012).

${ }^{5}$ For recent studies of proportionality, see, eg, Eon Daly, 'Republicanizing Rights? Proportionality, Justification and Non-Domination' in Ester Herlin-Karnell and others (eds), Constitutionalism Justified: Rainer Forst in Discourse (OUP 2019).

${ }^{6}$ Mattias Kumm, 'The Idea of Socratic Contestation and the Right to Justification: The Point of Rights-based Proportionality Review’ (2010) 4(2) Law \& Ethics of Human Rights 141.

${ }^{7}$ See, for example, Barak (n 2); Jud Mathews and Alec Stone Sweet, 'All Things in Proportion? American Rights Doctrine and the Problem of Balancing’ (2010) 60 Emory Law Journal 797; Kai Möller, The Global Model of Constitutional Rights (OUP 2012); Moshe Cohen-Eliya and Iddo Porrat, Proportionality and Constitutional Culture (CUP 2013); Jacob Weinrib, Dimensions of Dignity: The Theory and Practice of Modern Constitutional Law (CUP 2016) ch 7.
} 


\section{THE GRAND DEBATE ON PROPORTIONALITY IN A NUTSHELL ${ }^{8}$}

The principle of proportionality has been key to the development of EU law and plays a central role in constitutional law in general. Proportionality reasoning is then connected not only to the question of the quality of arguments, but also to the question of reasonable disagreement. ${ }^{9}$ In this regard the idea of proportionality is closely linked to justice-based reasoning. For example, applying a Rawlsian account to the theory of justice would, probably, imply using reasonableness as an adequate standard for measuring legitimacy at EU level. ${ }^{10}$ As Malcolm Thorburn argues, courts assess justifications by asking whether the infringement was prescribed by law, and whether it was undertaken in furtherance of a legitimate state purpose. These considerations play an essential part in the justification process. Taken together, they mean that no one can use the powers of the state to infringe constitutional rights on his or her own private say-so (where the act was not prescribed by law) or for his or her own private purpose (rather than a legitimate public purpose). Furthermore, the requirement of a legitimate state purpose also excludes any purpose that is at odds with the regime of constitutional rights. ${ }^{11}$ Yet for Robert Alexy, for example, the reasonableness test is not sufficient, in that there are cases which require a much closer review than an absurdity test in terms of what is to be counted as 'reasonable' can provide. ${ }^{12}$ Therefore, for him, correctness as a regulatory idea means that it is open to future argumentation and strives towards the dimension of the absolute.

With regard to the EU, as noted, the Member States could invoke proportionality to derogate from the rights guaranteed in the Charter since Article 52 applies to all rights. Yet, the Charter refers to the ECHR in Article 52(3) in pointing out that the ECHR is always the minimum standard of protection, which means that also the EU Charter treats absolute rights as 'absolute'. The assumption is that interference with EU law rights should be kept to a minimum, in which the test is to ascertain whether it has been manifestly disproportionate to interfere with these rights. The CJEU will inquire as to whether the measure was suitable or appropriate to achieve the desired result or whether this could have been attained by a less onerous method. Proportionality is therefore a general review in EU law that is applicable to test the legality both of EU action, and of Member State action when the latter falls within the ambit of the Treaty. ${ }^{13}$ While the principle of proportionality is part of the EU's arsenal for deciding on legislative authority for the EU legislator, it is also a principle that is addressed to individuals in the freedom of movement context. This is usually called the strict proportionality test of the otherwise rather state-centric proportionality test. Hence, the individual plays an increasingly important role in the EU context. For example, Article 3 TFEU makes it clear that not only is the Union to aim to promote the well-being of its

\footnotetext{
8 This section builds on Ester Herlin-Karnell, The Constitutional Structure of Europe's Area of Freedom, Security and Justice and the Right to Justification (Hart Publishing 2019) ch 4.

9 John Rawls, Justice as Fairness: A Restatement (Harvard University Press 2001).

10 ibid.

${ }^{11}$ Malcolm Thorburn, 'Proportionality' in David Dyzenhaus and Malcolm Thorburn (eds), Philosophical

Foundations of Constitutional Law (OUP 2016).

12 Robert Alexy, 'The Absolute and the Relative Dimensions of Constitutional Rights' (2017) 37 (1) Oxford Journal of Legal Studies 31.

13 Paul Craig, 'Proportionality, Rationality and Review' [2010] New Zealand Law Review 265.
} 
peoples, but it is also to offer its citizens an area of freedom, security and justice without internal frontiers, in which the free movement of persons is ensured in conjunction with appropriate measures with respect to, among other things, the prevention and combating of crime. This implies a balance not only vis-à-vis the EU and its Member States, but also between the individual and the EU. ${ }^{14}$

The principle of proportionality is designed for looking at the question of the reason for any derogations and on the question of what counts as good reasons. Thus, the question of 'good reason' is very important as proportionality functions as a justification tool in this regard. But, who decides which reasons are good enough? For Forst, 'good reasons are not to be found in ethical principles alone, but in an evaluative space of communal values and self-understanding. ${ }^{15}$ In this way, discourse truly articulates what belongs to the character of the community. For him, this means that a good reason is a substantive one and is, as such, ethical, as a citizen needs to understand himself or herself as part of a community which is internally connected to the common good. Forst anchors this in the idea of legitimacy. The main commitment would not be to democracy itself, but to the values that a community holds dear, meaning that democracy is not autonomous, but is itself ruled by communal values. ${ }^{16}$

Notwithstanding the attractiveness of proportionality as a judicial principle, proportionality is often attacked on the grounds that it involves judicial weighing of incommensurables, and thereby erodes rights. Moreover, it is often accused of being far too pragmatic and thus simply too mechanical as a legal principle. The argument hinges on the concern that moral values cannot be adequately balanced, as the interests at stake cannot actually be weighed on any sort of scale. ${ }^{17}$ In short, critics argue that there is too much ambiguity with the pathologies of the proportionality test, and that it fails to deliver what it promises, namely, that, contrary to what some scholars argue, it increases neither transparency nor rationality, and thus has no legitimacy. Another critique is that often not enough information is, empirically speaking, available in the proportionality cases, which makes it difficult to rule on the facts and strike a balance. ${ }^{18}$ The principle of proportionality much like justice, is vulnerable to the critique that its political dimension means that it is not amenable to judicial review.

What then justifies giving so much power to courts? According to some scholars in order to determine more precisely when the competence of courts is supported by democratic legitimacy, we may employ the three key values of democracy: accountability; participation; and equality. ${ }^{19}$ As Matthias Klatt has described it: 'The more serious a limitation of rights is, the more intense should be the review engaged in by the court'. ${ }^{20}$ But, as David Beatty notes:

\footnotetext{
14 Tridimas (n 1).

${ }^{15}$ Forst (n 4) 172, discussing Taylor's work - see, eg, Charles Taylor, The Ethics of Authenticity (Harvard University Press 1992).

${ }^{16}$ Forst (n 4) 173.

17 Timothy Endicott, 'Proportionality and Incommensurability' (2012) No 40/2012 Oxford Legal Research Papers.

18 Bernhard Schlink, 'Proportionality in Constitutional Law: Why Everywhere but Here?' (2012) 22 Duke Journal of Comparative and International Law 291.

${ }^{19}$ Matthias Klatt, 'Positive Rights: Who Decides? Judicial Review in Balance' (2015) 13(2) International Journal of Constitutional Law 354.

20 ibid.
} 
Although it would seem to count in favour of the proportionality principle that it satisfies Dworkin's twin criteria of 'fit' and 'value' better than any rival theory, some may worry that its empirical and moral claims leave it open to a fundamental, potentially fatal objection. ${ }^{21}$

Clearly, the debate is connected to the classic debate in constitutional theory about the legitimacy of judicial review and to what extent rights can be limited. The idea of a 'justification-blocking function' of human rights is akin to Dworkin's view of human rights as trumps that can be deployed against policy arguments in legal discourse. ${ }^{22} \mathrm{He}$ points out that 'Rawls argues that: "Each person possesses an inviolability founded on justice that even the welfare of society as a whole cannot override". ${ }^{23}$ Also, Jürgen Habermas cautions against reducing the idea of human rights to policy arguments, observing that: if in cases of collision all reasons can assume the character of policy arguments, then the fire wall erected in legal discourse by a deontological understanding of legal norms and principles collapses' ${ }^{24}$

Regardless of the answer to the big question of how much proportionality and how much judicial review and what it tells us about the legitimacy of the system, it is clear that the EU court acts as a constitutional court with regard to the data protection cases.

\section{RECENT CASES ON PROPORTIONALITY AND DATA PROTECTION}

Why then is proportionality so central in the context of EU data protection?

The principle of proportionality has played a key role for ensuring data protection. After all, the recent case of for example the Digital Rights case, ${ }^{25}$ and the Schrems and Tele 2 Sverige cases are instructive as they stress the importance of data protection and proportionality. In Digital Rights, the Court annulled the 2006 Data Retention Directive, which was aimed at fighting crime and terrorism, and which allowed data to be stored for up to two years. It concluded that the measure breached proportionality on the grounds that the Directive had too sweeping a generality and therefore violated, inter alia, the basic right of data protection as set out in Article 8 of the Charter. The Court pointed out that access by the competent national authorities to the retained data was not made dependent on a prior review carried out by a court or by an independent administrative body whose decision sought to limit access to the data to what was strictly necessary for the purpose of attaining the objective pursued. Nor did it lay down a specific obligation on Member States designed to establish such limits. The EU legislator had provided insufficient justification - it was simply not good enough from the perspective of EU fundamental rights protection

The approach was confirmed in Schrems $I^{26}$ and subsequently in Schrems 2 and Tele 2 Sverige, where the Court held that:

\footnotetext{
${ }^{21}$ Beatty (n 2) 176; Ronald Dworkin, Law's Empire (Hart Publishing 1998).

22 Yutaka Arai-Takahashi, 'Proportionality' in Dinah Shelton (ed), The Oxford Handbook of International Human Rights Law (OUP 2013) ch 19.

23 ibid.

24 Jürgen Habermas, Between Facts and Norms (Oxford: Polity Press 1996) 258-9, also discussed in AraiTakahashi (n 22).

25 Opinion of Advocate General Cruz Villalón, Case C-293/12 Digital Rights Ireland and Seitlinger and Others (Digital Rights) ECLI:EU:C:2013:845.

${ }^{26}$ Case C-362/14 Maximillian Schrems v Data Protection Commissioner (Schrems I) ECLI:EU:C:2015:650.
} 
[L]egislation not providing for any possibility for an individual to pursue legal remedies in order to have access to personal data or to obtain the rectification or erasure of such data, does not respect the essence of the fundamental right to effective judicial protection, as enshrined in Article 47 of the Charter.

In view of the important role played by the protection of personal data in the light of the fundamental right to respect for private life and the extent and seriousness of the interference with that right caused by Directive 2006/24, the EU legislature's discretion is reduced, with the result that review of that discretion should be strict. Both the AG and the Court in Schrems II stressed that according to Article 52(1) of the Charter, any limitation on the exercise of the rights recognised by the Charter must genuinely meet an objective of general interest recognised by the Union. Article 8(2) of the Charter also provides that any processing of personal data that is not based on the consent of the person concerned must have a 'legitimate basis laid down by law'. The AG pointed out Article 8(2) of the ECHR lists the aims capable of justifying interference with the exercise of the right to respect for private life.

So in Scbrems II, the Court held that, it follows from the judgment in Schrems I that

legislation is not limited to what is strictly necessary where it authorises, on a generalised basis, storage of all the [data] without any differentiation, limitation or exception being made in the light of the objective pursued and without an objective criterion being laid down by which to determine the limits of the access of the public authorities to the data, and of its subsequent use, for purposes which are specific, strictly restricted and capable of justifying the interference which both access to that data and its use entail. ${ }^{27}$

These findings were also confirmed in Opinion 1/15 where the Court annulled a pending Agreement between Canada and the EU on the transfer and processing of Passenger Name Record (PNR) data. ${ }^{28}$ Here the Court held that the Agreement granted too sweeping a purpose of fighting terrorism without concrete justification in the individual case just simply a general concern of public security and without respecting private life and data protection (Articles 7 and 8 of the Charter, Article 16 TFEU) and proportionality (Article 52 of the Charter).

Moreover, the important role of proportionality was once again confirmed in the recent case of Privacy International affirming that mass surveillance without any justification or concrete suspicion presented, much in line with the Digital Rights case, mentioned above, is contrary to EU data protection as it does not stand the proportionality test. ${ }^{29}$ Similarly, in $\mathrm{La}$ Quadrature $d u$ Net, an obligation requiring the general and indiscriminate retention of traffic

\footnotetext{
27 Summary of Case C-311/18 Facebook Ireland and Schrems (Schrems II) ECLI:EU:C:2020:559, $<$ https: / curia.europa.eu/juris/document/document.jsf?text=\&docid=182494\&pageIndex $=0 \&$ doclang $=$ en $\&$ mode $=$ req\&dir $=\& o c c=$ first\&part $=1 \& c i d=97149>$ accessed on 11 December 2021, para 8 (with reference to paras $91-95$ of Schrems II judgment).

28 Opinion 1/15 On the draft agreement between Canada and the European Union on the transfer and processing of Passenger Name Record data (Opinion 1/15) ECLI:EU:C:2017:592.

${ }^{29}$ Case C-623/17 Privacy International v Secretary of State for Foreign and Commonwealth Affairs and Others (Privacy International) ECLI:EU:C:2020:790.
} 
and location data is incompatible with the Charter. ${ }^{30}$ The Court emphasized that legislation which permits the general and indiscriminate transmission of data to public authorities entail general access and that national legislation requiring providers of electronic communications services to disclose traffic data and location data to the security and intelligence agencies by means of general and indiscriminate transmission exceeds the limits of what is strictly necessary and cannot be considered to be justified, within a democratic society. ${ }^{31}$

The crucial point here is that the proper application of proportionality functions as a rebuttal to the EU legislator or the Member States, if the reasons provided are not deemed good enough. When constitutional rights are at stake, there needs to be a good justification for relying on trust. Therefore, as noted it could be argued that the scope of data protection under the Charter turns on the width of the proportionality principle. Although the Member States could invoke proportionality to derogate from the rights guaranteed in the Charter, since Article 52 applies to all rights, there are limits in the light of dignity and the rule of law (EU law principles). Nonetheless, the explanatory memorandum on the Charter confirms that these exceptions are based upon the Court's well-established case law that restrictions may be imposed on the exercise of fundamental rights. ${ }^{32}$

While the principle of proportionality is part of the EU's arsenal for deciding on the legislative authority for the EU legislator, it is also a principle that is addressed to individuals in the free movement context. This is usually called the strict proportionality aspect of the otherwise rather state-centric proportionality test.

In Opinion 1/15 where the Court annulled a pending Agreement between Canada and the EU on the transfer and processing of Passenger Name Record (PNR) data. ${ }^{33}$ The Court held that the Agreement granted too sweeping a purpose of fighting terrorism without concrete justification in the individual case just simply a general concern of public security and without respecting private life and data protection (Articles 7 and 8 of the Charter, Article 16 TFEU) and proportionality (Article 52 of the Charter). The PNR Agreement would have permitted data retention for up to five years. ${ }^{34}$ The Court specifically stated that the Agreement needs to limit the retention of passenger name record after departure to that of passengers in respect of whom there is objective evidence from which it may be inferred that they may present a risk in terms of the fight against terrorism. ${ }^{35}$

Much of EU law is contingent on the proportionality principle, as it is concerned with constitutional rights: it could be argued that the scope of EU human-rights protection under the Charter seems to turn on the width of the proportionality principle. After all, the Member States could invoke proportionality to derogate from the rights guaranteed in the Charter and this applies to all rights. The explanatory memorandum on the Charter confirms that these exceptions are based upon the Court's well-established case law that restrictions may

\footnotetext{
30Joined Cases C-511/18, C-512/18 and C-520/18 La Quadrature du Net and Others v Premier ministre and Others (La Quadrature du Net) ECLI:EU:C:2020:791

31 The Court refers to Article 15(1) of Directive 2002/58, read in the light of Article 4(2) TEU and Articles 7, 8 and 11 and Article 52(1) of the Charter.

${ }^{32}$ Explanations relating to the Charter of Fundamental Rights (Explanations to the EU Charter) [2007] OJ C303/17.

33 Opinion $1 / 15$ (n 28).

34 ibid paras 154-78.

35 ibid para 232.
} 
be imposed on the exercise of fundamental rights. ${ }^{36}$ The explanatory notes also make it clear that the reference to the general interests recognised by the Union covers both the objectives mentioned in Article 3 TEU and other interests protected by specific provisions of the Treaties provided that those restrictions do, in fact, correspond to the objectives of general interest pursued by the Community and do not constitute, with regard to the aim pursued, disproportionate and unreasonable interference which undermines the very substance of those rights. ${ }^{37}$ Indeed, the Charter refers to the ECHR in Article 52(3) in pointing out that the ECHR is always the minimum standard of protection.

\section{SWEDEN AS A TEST CASE OF (MISSING) PROPORTIONALITY}

As I have previously argued in this journal, the Swedish system is an interesting case of (what I would call) a flagrant breach of the GDPR and primary EU law when it comes to data protection. ${ }^{38}$ More specifically, Sweden has a very peculiar system with regard to EU data protection and one which is very interesting in the context of proportionality. Anyone who buys a publishing license from the state is exempted from the GDPR, the argument goes, because it gives them the freedom of expression and the right to publish. ${ }^{39}$ Largely absent from this claimed derogation from the GDPR, however, is the question as to whether the Swedish exception breaches primary EU law on data protection (Article 16 TFEU and Article 8 EU Charter), as well whether the exception from the GDPR is proportionate. Buying a license without much scrutiny gives a carte blanche to share information about individuals. ${ }^{40}$ This seems not only wrong but also a disproportionate weight between different rights (ie, the right to publish if you buy a license and the right to data protection of individuals). The problem here is not about journalistic freedom because traditional media is bound by press ethics, while companies that buy a license get access to bulk data of all Swedish residents. The companies in turn can sell the data and make it available on the internet, thereby infringing EU data protection. In addition, these private actors who buy those licenses can earn a profit from advertisement when publishing information about individuals and in certain cases they even sell the information. ${ }^{41}$ This seems not to be about freedom of expression and of the right to publish (as important rights in a democratic society), but rather about conducting business. Likewise, if the argument is one of general concern for freedom of expression and rights in the Swedish constitution (grundlagen) there is something important missing here, namely a proportionality assessment as there needs to be a balance between competing rights. Any derogations from EU law must be justified. In addition, it seems strange to favour business over individual data protection (and of course if people agree to have their personal data published on the internet, it is no problem). Therefore, if there is no consent at least there has to be a proportionality assessment, and a balance between a Swedish 'right' to buy information and publish it and that of an individual's right

\footnotetext{
${ }^{36}$ Explanations to the EU Charter (n 32).

37 ibid.

${ }^{38}$ Ester Herlin-Karnell, 'EU Data protection Rules and the Lack of Compliance in Sweden' (2020)

3(2) NordicJournal of European Law 95.

39 Myndigheten för press, radio och tv, 'Utgivningsbevis' < http://www.mprt.se/sv/att-

sanda/internetpublicering/utgivningsbevis/> accessed 11 December 2021.

$40 \mathrm{ibid}$, it costs SEK 2,000 for a licence obtaining.

${ }^{41}$ See, eg, MrKoll.se website (Bättre koll på privatpersoner) < https://mrkoll.se> accessed 11 December 2021.
} 
to private life, dignity and data protection according to EU law. And of course, EU law is primary to national law.

There is also an external dimension. As explained above, in several recent cases such as Digital Rights and Schrems 1 \& 2, the CJEU has stressed the EU's data protection rules cannot be derogated from without any justification. The proportionality review and the need to secure equivalent protection of data protection in cooperation with third states is interesting in the Swedish case. When data is published online it also become a global question as the data is available to third countries also. From this perspective it could be argued that, actually, EU data protection rules are not complied with when it comes to the importance of upholding EU standards with regard to third states. Therefore, it could be questioned whether data protection in the EU is not lived up to vis-à-vis third countries. ${ }^{42}$

\section{CONCLUSION}

The principle of proportionality continues to play a central role in EU integration. It appears to be a key principle in the area of data protection. This is neither strange or new: EU data protection is treated as a constitutional right and the principle of proportionality is used as a balancing principle balancing different rights at the constitutional level - and boils down to what we make of the proportionality test.

The idea that Member States can derogate from constitutional duties, if it can be justified, is a common feature of human rights law including EU law. Article 16 TFEU and Article 8 the Charter are formulated as rights. It should also be stressed that in the Schrems 1 \& 2 the Court held that:

[L]egislation not providing for any possibility for an individual to pursue legal remedies in order to have access to personal data or to obtain the rectification or erasure of such data, does not respect the essence of the fundamental right to effective judicial protection, as enshrined in Article 47 of the Charter. ${ }^{43}$

The Union is founded on the values of respect for human dignity, freedom, democracy, equality, the rule of law and respect for human rights, including the rights of persons belonging to minorities (Article $2 \mathrm{TEU}$ ). But how this is achieved at EU level is trickier. And this is where the role of courts and the application of proportionality is both interesting and important.

Clearly, the debate is connected to the classic debate in constitutional theory about the legitimacy of judicial review. The balancing test is surely the most important aspect of the principle of proportionality when applied in the context of EU data protection. As the case of Sweden demonstrates with regard to the peculiar system of publishing license and where national practice is considered to stand above EU law on data protection, what is largely missing to the Swedish debate is exactly the principle of proportionality and the supremacy of EU law.

\footnotetext{
${ }^{42}$ Herlin-Karnell (n 38).

43 Schrems II (n 27) para 187, with reference to Schrems I (n 26) para 95.
} 


\section{LIST OF REFERENCES}

Alexy R, 'The Absolute and the Relative Dimensions of Constitutional Rights' (2017) 37(1) Oxford Journal of Legal Studies 31.

DOI: https://doi.org/10.1093/ojls/gqw013

Arai-Takahashi Y 'Proportionality' in Shelton D (ed), The Oxford Handbook of International Human Rights Law (OUP 2013).

Barak A, Proportionality: Constitutional Rights and their Limitations (CUP 2012).

Beatty D M, The Ultimate Rule of Law (OUP 2004).

DOI: https://doi.org/10.1093/acprof:oso/9780199269808.001.0001

Bernitz X, Groussot X, Paju J, de Vries S (eds.), General Principles of EU Law and the EU Digital Order (Wolters Kluwer 2020).

Cohen-Eliya M and Porrat I, Proportionality and Constitutional Culture (CUP 2013).

DOI: https://doi.org/10.1017/cbo9781139134996

Craig P, 'Proportionality, Rationality and Review' (2010) New Zealand Law Review 265.

Daly E, 'Republicanizing Rights? Proportionality, Justification and Non-Domination' in Herlin-Karnell E, Klatt M, Morales Zúñiga H A (eds), Constitutionalism Justified: Rainer Forst in Discourse (OUP 2019).

DOI: https://doi.org/10.1093/oso/9780190889050.003.0009

Dworkin R, Law's Empire (Hart Publishing 1998).

Endicott T, 'Proportionality and Incommensurability' (2012) No 40/2012 Oxford Legal Research Papers.

Forst R, The Right to Justification (Columbia University Press 2012).

Habermas J, Between Facts and Norms (Oxford: Polity Press 1996).

DOI: $\underline{\text { https://doi.org/10.7551/mitpress/1564.001.0001 }}$

Herlin-Karnell E, 'EU Data protection Rules and the Lack of Compliance in Sweden' (2020) 3(2) Nordic Journal of European Law 95.

DOI: https://doi.org/10.36969/njel.v3i2.22395 
- - The Constitutional Structure of Europe's Area of Freedom, Security and Justice and the Right to Justification (Hart Publishing 2019).

DOI: https://doi.org/10.5040/9781509912520

Klatt M, 'Positive Rights: Who Decides? Judicial Review in Balance' (2015) 13(2) International Journal of Constitutional Law 354.

DOI: https://doi.org/10.1093/icon/mov019

Kumm M, 'Alexy's Theory of Constitutional Rights and the Problem of Judicial Review' in Klatt M (ed), Institutionalized Reason: The Jurisprudence of Robert Alexy (OUP 2012).

DOI: https://doi.org/10.1093/acprof:oso/9780199582068.003.0009

- - 'The Idea of Socratic Contestation and the Right to Justification: The Point of Rightsbased Proportionality Review' (2010) 4(2) Law \& Ethics of Human Rights 141.

DOI: https://doi.org/10.2202/1938-2545.1047

Stone Sweet M, 'All Things in Proportion? American Rights Doctrine and the Problem of Balancing’ (2010) 60 Emory Law Journal 797.

Möller K, The Global Model of Constitutional Rights (OUP 2012).

DOI: https://doi.org/10.1093/acprof:oso/9780199664603.001.0001

Rawls J, Justice as Fairness: A Restatement (Harvard University Press 2001).

Schlink B, 'Proportionality in Constitutional Law: Why Everywhere but Here?' (2012) 22 Duke Journal of Comparative and International Law 291.

Taylor C, The Ethics of Authenticity (Harvard University Press 1992).

DOI: https://doi.org/10.2307/j.ctvv41887

Thorburn M, 'Proportionality' in Dyzenhaus D and Thorburn M (eds), Philosophical Foundations of Constitutional Law (OUP 2016).

DOI: https://doi.org/10.1093/acprof:oso/9780198754527.003.0016

Tridimas T, General principles of EU Law (OUP 2012).

Weinrib D, Dimensions of Dignity: The Theory and Practice of Modern Constitutional Law (CUP 2016). 